\title{
Relationship between antioxidative potential and amino acids composition of the bioactive peptides prepared from Indian squid Uroteuthis (Photololigo) duvaucelii (d'Orbigny, 1835) using alcalase
}

\author{
FATHIRAJA PARTHIBAN, ROBINSON JEYA SHAKILA*, GEEVARETNAM JEYASEKARAN \\ AND RAJENDRAN SHALINI \\ Fisheries College and Research Institute, Tamil Nadu Fisheries University, Tuticorin - 628 008, Tamil Nadu, India \\ e-mail: jeyashakila@gmail.com
}

\begin{abstract}
Biopeptides derived from fish protein hydrolysates are gaining popularity as active ingredients in functional foods. In this study, squid protein hydrolysates (SPH) prepared from Uroteuthis (Photololigo) duvaucelii, using alcalase and their biopeptides fractionated using ultrafiltration were investigated for their antioxidant properties in relation to the changes in their amino acid profiles. Squid mantle hydrolysed within 30 min with a degree of hydrolysis (DH) of $13.7 \%$. SPH had $89 \%$ 2, 2-diphenyl-1- picrylhydrazyl (DPPH) inhibition, 94\% 2, 2-azino-bis-(3-ethylbenzothiazoline-6-sulphonicacid) (ABTS) inhibition and $96 \%$ hydroxyl inhibition at $10 \mathrm{mg} \mathrm{ml}^{-1}$ concentration. In the squid peptides, DPPH inhibition increased with the decrease in the molecular size of peptides from $51 \%$ to $95 \%$ ( $3 \mathrm{Ka}$ ), ABTS radical inhibition was $<42 \%$ for peptides with $>5 \mathrm{KDa}$ size and $>95 \%$ for peptides with $<5 \mathrm{KDa}$. Hydroxyl radical inhibition increased from $75-98 \%$ with decrease in molecular size. Increase in glycine, alanine, leucine and taurine was noticed in peptides with MW $<5 \mathrm{KDa}$ along with a decrease in methionine and arginine. Histidine, asparagine and tyrosine had also contributed to the activities of peptides with MW 3-5 KDa sizes. This study indicated that peptides with $\mathrm{MW}<5 \mathrm{KDa}$ had more free radicals scavenging activities with more hydrophobic amino acids, tyrosine and taurine which are mainly responsible for antioxidative properties. Therefore, squid peptides with $\mathrm{MW}<5 \mathrm{KD}$ a prepared using alcalase have potential to serve as nutraceuticals.
\end{abstract}

Keywords: Alcalase, Amino acid, Antioxidative, Biopeptides, Hydrolysate, Indian squid

\section{Introduction}

Fish are rich source of structurally diverse bioactive compounds used to promote consumer health as well as to improve the shelf life of food products. Fish protein hydrolysates (FPH) and their peptides exert various biological activities. Antioxidative properties of several fish protein hydrolysates derived from muscle, skin and bone have been reported by several authors (Byun and Kim, 2001; Wu et al., 2003; Mendis et al., 2005; Je et al., 2007; Thiansilakul et al., 2007; Yang et al., 2008 a,b; Gimenez et al., 2009; Hsu et al., 2009). Studies on the antioxidative properties of squid protein hydrolysates (SPH) and their bioactive peptides derived from Indian squid in relation to their amino acid composition are quite limited. Studies in this line have been carried out earlier on the giant squid skin (Mendis et al., 2005, Gimenez et al., 2009) as well as muscle (Rajapakse et al., 2005).

Peptides, that are usually inactive within the parent protein, can be released as an active compound by the action of plant, animal and microbial enzymes (Hoyle et al., 1994; Simpson et al., 1998; Aspmo et al., 2005; Viera et al., 1995).
Alcalase is a microbial alkaline enzyme produced by Bacillus licheniformis that is highly efficient in the production of bioactive compounds (Kristinsson and Rasco, 2000). It hydrolyses the peptide bonds of aliphatic or aromatic amino acids such as leucine, phenylalanine, tyrosine and tryptophan (Rao et al., 1998). Studies carried out with different enzymes have proven that FPH prepared using alcalase exhibited high antioxidative properties (Thiansilakul et al., 2007). Peptides isolated from FPH usually consist of 3-20 amino acid residues (Pihlanto-Leppala, 2001) and their activities are based on their structural properties, molecular size, amino acid composition and their sequence (Arihara, 2004; Kim and Wijesekara, 2010).

Amino acid residues such as histidine, leucine, tyrosine, methionine and cysteine are associated with radical scavenging activity while hydrophobic amino acids such as proline and hydroxyproline appear to play an important role in the inhibition of lipid peroxidation (Mendis et al., 2005; Sarmadi and Ismail, 2010). Free radical quenching has been reported to be the main antioxidative mechanism of the peptides due to the amino acids, especially proline, alanine, valine and leucine (Mendis et al., 2005). The antioxidant 
properties of fish peptides are not attributable to a single antioxidant mechanism as the properties derived by the peptides were mainly due to the presence of different amino acids favouring one mechanism over others. Taking into consideration all the above aspects, the present study was undertaken with the aim to utilise the Indian squid Uroteuthis (Photololigo) duvaucelii to prepare squid protein hydrolysate (SPH) and their biopeptides using alcalase, as a maiden study. The antioxidative properties of the squid peptides in relation to the changes in the amino acid composition were also examined.

\section{Materials and methods}

The Indian squid $U$. (P.) duvaucelii caught by trawl net were obtained from Thoothukudi Fishing Harbour, Tamil Nadu, India. Alcalase enzyme was obtained from Novozyme, Bagsvaerd, Denmark. Chemicals such as 2, 2-diphenyl-1-picrylhydrazyl (DPPH); 2, 2-azino-bis-(3-ethylbenzothiazoline-6-sulphonicacid) (ABTS); 2,4,6-tripyridyl-s-triazine (TPTZ) and 2, 4, 6-trinitrobenzenesulfonic acid (TNBS) were purchased from Sigma-Aldrich, St. Louis, Missouri, USA. Nitro blue tetrazolium (NBT), nicotinamide adenine dinucleotide sodium salt monohydrate (NADH), phenazine methosulphate (PMS), potassium persulphate, sodium salicylate, L-leucine and potassium ferricyanide were procured from Hi-Media Laboratories India Pvt. Ltd., Mumbai. Ferrous chloride $\left(\mathrm{FeCl}_{2}\right)$ was purchased from Alfa-acer Heysham, England. Amino acid standards $\mathrm{H}$ were procured from Thermoscientific Pvt. Ltd., Meridian Rd., Rockford, U.S.A. Nanosep ${ }^{\circledR}$ Centrifugal tubes with molecular weight cutoffs (MWCO) $30 \mathrm{KDa}$ and $10 \mathrm{KDa}$ were purchased from Pall Life Sciences Ann Arbor Michigan, Mexico and Vivaspin molecular weight cutoffs (MWCO) $5 \mathrm{KDa}$ and $3 \mathrm{KDa}$ were purchased from Sartorius Stedim Biotech, Gottingen, Germany. All other chemicals like ferric chloride $\left(\mathrm{FeCl}_{3}\right)$, trichloroacetic acid (TCA), ferrous sulphate, hydrogen peroxide, potassium ferric cyanide, sodium acetate, sodium hydroxide, sodium dihydrogen phosphate, disodium hydrogen phosphate, butylated hydroxyl anisole (BHA) and Vitamin C were commercially available and were of analytical grade.

\section{Optimisation of enzyme hydrolysis}

Squids were gutted and deskinned manually to separate the mantle tissues and skin for the enzyme hydrolysis. Raw muscle tissue was hydrolysed using alcalase at a ratio of 1:100:200 (enzyme:sample:50 mM sodium phosphate buffer), under optimum $\mathrm{pH}$ of 8.0 and $50^{\circ} \mathrm{C}$ (Klompong et al., 2007). Hydrolysis was initially carried out in a serological water bath for a total duration of $180 \mathrm{~min}$. Samples were drawn after every $5 \mathrm{~min}$ to test the degree of hydrolysis. The reaction was finally terminated by increasing the temperature to $70^{\circ} \mathrm{C}$ for 15 min. The hydrolysate was filtered through Whatman No.1 filter paper and centrifuged at $10,000 \mathrm{rpm}$ for $15 \mathrm{~min}$ at $4{ }^{\circ} \mathrm{C}$ in a refrigerated centrifuge (Hettich, Germany).

\section{Degree of hydrolysis}

Degree of hydrolysis (DH) was calculated by determination of free amino group after reaction with TNBS following the method described by Adler-Nissen (1986) and Crowell et al. (1985) with slight modification. About $0.25 \mathrm{ml}$ of SPH was pipetted out into $2.0 \mathrm{ml}$ of aqueous $1 \%$ SDS and incubated at $70^{\circ} \mathrm{C}$ for $15 \mathrm{~min}$. From this, $0.25 \mathrm{ml}$ was transferred into test tube containing $2.0 \mathrm{ml}$ of $0.2 \mathrm{~m}$ sodium phosphate buffer ( $\mathrm{pH} 8.2$ ). A blank was set using $0.25 \mathrm{ml}$ of $1 \%$ SDS. Then, $2 \mathrm{ml}$ of TNBS reagent $(0.1 \% \mathrm{w} / \mathrm{v})$ was added, mixed well, covered with aluminum foil and incubated in dark at $50^{\circ} \mathrm{C}$ for $50 \mathrm{~min}$. The reaction was then terminated by the addition of $4.0 \mathrm{ml}$ of $0.1 \mathrm{~N} \mathrm{HCl}$ and cooled at room temperature for $30 \mathrm{~min}$. The absorbance was read at $420 \mathrm{~nm}$ in a UV-Vis. spectrophotometer (Model V-531, JASCO, Japan). The amount of free amino group liberated was expressed as L-leucine equivalent. The DH was determined following the equation given by Beak and Cadwallader (1995).

$$
\mathrm{DH}=\left[\left(\mathrm{L}_{\mathrm{t}}-\mathrm{L}_{0}\right) /\left(\mathrm{L}_{\max }-\mathrm{L}_{0}\right)\right] \times 100
$$

where $L_{t}$ corresponds to the amount of $\alpha$-amino acid released at time $t ; L_{0}$ is the amount of $\alpha$-amino acid in original muscle; $\mathrm{L}_{\text {max }}$ is the maximum amount of $\alpha$-amino acid in muscle.

To determine the total $\alpha$-amino acids, $0.5 \mathrm{~g}$ of mantle tissue taken in a test tube was mixed with $4.5 \mathrm{ml}$ of $6 \mathrm{~N} \mathrm{HCl}$, flushed with nitrogen gas, sealed tightly and hydrolysis was carried at $100^{\circ} \mathrm{C}$ for $24 \mathrm{~h}$ in a hot air oven (Dalal, New Delhi). After the hydrolysis, it was cooled, filtered and then neutralised with $6 \mathrm{~N} \mathrm{NaOH}$ prior to the determination by TNBS reagent.

\section{Biopeptides fractionation}

Biopeptides were separated from the SPH based on their molecular weight cutoffs (MWCOs), using ultrafiltration centrifugal tubes. SPH $(0.5 \mathrm{ml})$ was taken in the centrifugal tube having $\mathrm{MWCO}<30 \mathrm{KDa}$ filter and centrifuged at 10,000 rpm for $10 \mathrm{~min}$, to obtain $>30 \mathrm{KDa}$ and $<30 \mathrm{KDa}$ peptide fractions. The $<30 \mathrm{KDa}$ fraction was again transferred into the centrifugal tube having MWCO $10 \mathrm{KDa}$ filter and centrifuged at $10,000 \mathrm{rpm}$ for $10 \mathrm{~min}$ to get $30-10 \mathrm{KDa}$ and $<10 \mathrm{KDa}$ biopeptides fractions. The $<10 \mathrm{KDa}$ fraction was further separated in similar manner to obtain 10-5 KDa, $<5 \mathrm{KDa}, 5-3 \mathrm{KDa}$ and $<3 \mathrm{KDa}$ peptide fractions using the respective MWCO filters. The concentration of biopeptides in each fraction was estimated following Lowry et al. (1969).

\section{Total amino acid profile}

Amino acid composition was determined by first hydrolysing the samples according to the method of Ishida et al. (1981). Peptide samples were taken in tubes, 
sealed in a stream of nitrogen gas and hydrolysed using $6 \mathrm{~N} \mathrm{HCl}$ by placing the tubes in a hot air oven (Technico, India) set at $110^{\circ} \mathrm{C}$ for $24 \mathrm{~h}$. After hydrolysis, the samples were filtered through Whatman No.1 filter paper to remove the unhydrolysed debris and neutralised with $6 \mathrm{~N} \mathrm{NaOH}$. Neutralised samples were filtered again through a PTFE syringe filter of $0.2 \mu \mathrm{m}$ diameter (Cole Parmer, East Bunker Court Vernon Hills, USA). Filtered samples were derivatised using the AccQ. Tag Ultra precolumn derivatisation kit. For derivatisation, $10 \mu \mathrm{l}$ of filtrate was mixed with $70 \mu \mathrm{l}$ of AccQ. Tag Ultra Borate buffer and $20 \mu$ l of reconstituted Acc Q Tag Ultra derivatisation reagent. Derivatised samples were transferred into auto sampler maximum recovery vials of capacity $2 \mu 1$.

Amino acid derivatives were then separated in the Waters ACQUITY-UPLC (Waters Corporation, Milford, USA) fitted with ACCQ-TAG ULTRA C18, $1.7 \mu \mathrm{m}$, $2.1 \times 100 \mathrm{~mm}$ column by gradient elution. Mobile phase consisted of two buffers, ACCQ-TAG ULTRA Eluent A containing acetonitrile and formalin and Eluent B containing

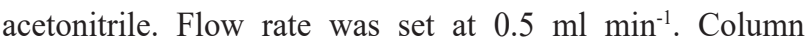
temperature was maintained at $55^{\circ} \mathrm{C}$. Gradient elution programme was followed setting a flow of $99.9 \%$ Eluent A initially and then progressing to $78.8 \%$ at $10.34 \mathrm{~min} ; 40.4 \%$ at $11.26 \mathrm{~min}$ and $10 \%$ at $11.27 \mathrm{~min}$. The total run time was 13.30 min. Amino acids were quantified based on their absorbance at $260 \mathrm{~nm}$ with the help of tunable UV detector and analysed using Empower 2 Software. Amino acid standards (Thermo Scientific, Rockford, USA) were also run simultaneously for calibration. Amino acids were identified with the help of authentic standards and represented in g 100 g protein $^{-1}$.

\section{Antioxidant properties}

To determine the antioxidant properties of the squid muscle hydrolysates during the hydrolysis reaction, $10-15 \mathrm{ml}$ of hydrolysate was withdrawn after every 5 min interval in the test tube and the reaction was terminated by incubation to $70^{\circ} \mathrm{C}$ for $15 \mathrm{~min}$. The reaction mixture was then centrifuged at $8000 \mathrm{rpm}$ for $10 \mathrm{~min}$ at $4^{\circ} \mathrm{C}$, neutralised to $\mathrm{pH} 7.0$ using either $\mathrm{HCl}$ or $\mathrm{NaOH}$ and filtered through syringe filter having $0.2 \mu \mathrm{m}$ dia (Polysulfone, Whatman, Florham Park, USA) to obtain a clear supernatant.

\section{DPPH radical scavenging activity}

DPPH radical scavenging activity was determined as per Wu et al. (2003) with slight modifications. SPH and their peptides $(1.5 \mathrm{ml})$ mixed with $1.5 \mathrm{ml}$ of $0.1 \mathrm{~mm}$ DPPH in $95 \%$ methanol were allowed to stand in dark for $30 \mathrm{~min}$; and the absorbance was measured at $517 \mathrm{~nm}, 50 \mathrm{mM}$ sodium phosphate buffer ( $\mathrm{pH}$ 7.2) was used as the control.
Standards were prepared using BHA and vitamin C at different concentration for comparison. All the activities were determined in triplicate.

DPPH radical scavenging activity $(\%)=[(\mathrm{A} 0-\mathrm{A} 1) / \mathrm{A} 0] \times 100 \%$

where, A0 is the absorbance of control and A1 is the absorbance of sample or standard.

ABTS radical scavenging activity

ABTS radical scavenging activity was determined as per the method of Shalaby (2013) with slight modification. Stock ABTS solution was prepared by incubating $7.0 \mathrm{mM}$ of ABTS with $2.45 \mathrm{mM}$ potassium persulfate for $12 \mathrm{~h}$ in dark, which was further diluted at the ratio of 1:30 using methanol to obtain an absorbance of $0.700=0.02$ at $734 \mathrm{~nm}$. ABTS solution was freshly prepared before use. For the assay, SPH and their peptides $(150 \mu \mathrm{l})$ mixed with $2.85 \mathrm{ml}$ of diluted ABTS solution were left for $2 \mathrm{~h}$ in dark and the absorbance was measured at $734 \mathrm{~nm} .50 \mathrm{mM}$ sodium phosphate buffer (pH. 7.2) served as the control. Standards were prepared using BHA and vitamin $\mathrm{C}$ at different concentrations for comparison. All the activities were determined in triplicate.

ABTS radical scavenging activity $(\%)=[(\mathrm{A} 0-\mathrm{A} 1) / \mathrm{A} 0] \times 100 \%$,

where, A0 is the absorbance of control and A1 is the absorbance of sample or standard.

\section{Hydroxyl radical scavenging activity}

Hydroxyl radical scavenging activity was measured according to the method developed by Smirnoff and Cumbes (1989). SPH and their peptides $(0.5 \mathrm{ml})$ were mixed with $1.0 \mathrm{ml}$ of $1.5 \mathrm{mM} \mathrm{FeSO} \cdot 7 \mathrm{H}_{2} \mathrm{O}, 0.7 \mathrm{ml}$ of $6 \mathrm{mM}$ hydrogen peroxide, $0.3 \mathrm{ml}$ of $20 \mathrm{mM}$ sodium salicylate and $1.0 \mathrm{ml}$ of distilled water and incubated at $37^{\circ} \mathrm{C}$ for $1 \mathrm{~h}$ prior to measurement of the absorbance at $562 \mathrm{~nm}$. A control was prepared with $50 \mathrm{mM}$ sodium phosphate buffer $(\mathrm{pH}$ 7.2). A salicylate blank was set similar to control but without sodium salicylate. Standards were prepared using BHA and vitamin $\mathrm{C}$ at different concentrations for comparison. All the activities were determined in triplicate.

Hydroxyl radical scavenging activity $=[1-(\mathrm{A} 1-\mathrm{A} 2) / \mathrm{A} 0] \times 100$

where, A0 is the absorbance of the control (without sample); A1 is the absorbance of the sample or standard; A2 is the absorbance of the control without sodium salicylate.

\section{Statistical analysis}

Results are presented as mean \pm standard error and significance of the difference between mean values was determined by one-way analysis of variance (ANOVA) coupled with Duncan's multiple range test using windows based statistical software SPSS 10. p-value of less than 0.05 was considered to be significant (Christensen, 1996). 


\section{Results and discussion}

\section{Degree of hydrolysis}

Biological activities of the SPH and biopeptides depend on the degree of hydrolysis (DH). DH curve of SPH prepared using alcalase at $50^{\circ} \mathrm{C}$ and $\mathrm{pH} 8.0$ is given in Fig. 1. The $\mathrm{DH}$ increased significantly to $13.7 \%$ within $30 \mathrm{~min}(\mathrm{p}<0.05)$; and thereafter, no further increase in DH was observed. In tuna skin and squid tunic gelatin hydrolysates produced using alcalase, the maximum DH achieved was $47.52 \%$ recorded after 150 min of hydrolysis, of which, $25-30 \%$ occurred within the first $5 \mathrm{~min}$ (Gomez Guillen et al., 2010). The round scad muscle hydrolysates prepared using alcalase had much higher DH of $60 \%$ (Thiansilakul et al., 2007), but in the muscle hydrolysate prepared from yellow stripe trevally, using alcalase, the maximum DH was only $20 \%$ after $30 \mathrm{~min}$ of hydrolysis (Klompong et al., 2007). In squid, tuna and halibut gelatin hydrolysates prepared using alcalase, the DH recorded were 31,26 and $19 \%$, respectively after $180 \mathrm{~min}$ of hydrolysis (Aleman et al., 2011).

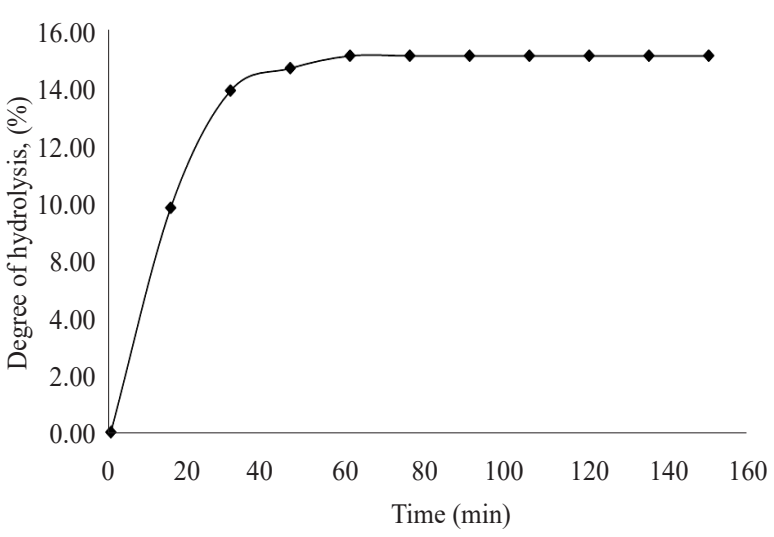

Fig.1. Degree of hydrolysis of SPH prepared using alcalase

The rate of hydrolysis by the alcalase on any substrate was quite fast in the initial stages and later reached a plateau, where no apparent change took place. We report DH either in terms of total $\alpha$-free amino acids or total nitrogen. The DH represented in terms of total nitrogen usually gave much higher values than those represented as $\alpha$-free amino acids. As recently, it has been indicated that $\mathrm{DH}$ has to be represented in terms of $\alpha$-free amino acids (Adler-Nissen,1986; AOAC, $1995)$ the same has been followed in this study.

\section{Amino acid profile}

The standard UPLC method could separate all the seventeen amino acids within the stipulated runtime with the retention times of histidine at $3.275 \mathrm{~min}$, serine $4.477 \mathrm{~min}$, arginine $4.717 \mathrm{~min}$, glycine $4.911 \mathrm{~min}$, aspartate $5.388 \mathrm{~min}$. glutamate $6.067 \mathrm{~min}$, threonine $6.613 \mathrm{~min}$, alanine $7.143 \mathrm{~min}$, proline $7.93 \mathrm{~min}$, cystine $9.102 \mathrm{~min}$, lysine $9.178 \mathrm{~min}$, tyrosine $9.356 \mathrm{~min}$, methionine $9.560 \mathrm{~min}$, valine
$9.717 \mathrm{~min}$, isoleucine $10.582 \mathrm{~min}$, leucine $10.684 \mathrm{~min}$ and phenylalanine at $10.808 \mathrm{~min}$. The linearity of the method is 0.25 to $2.5 \mu \mathrm{mol}$ of each amino acid. The LOD (Level of Detection) and LOQ (Level of Quantitation) of ACQUITYUPLC are $0.1 \mu \mathrm{mol}$ and $2.5 \mu \mathrm{mol}$ respectively.

Amino acid profile of SPH and their peptide fractions were examined to understand their role in relation to the antioxidative potential. Squid mantle consisted predominantly of glycine (15 mg $\left.100 \mathrm{mg}^{-1}\right)$, glutamic acid (12 mg $\left.100 \mathrm{mg}^{-1}\right)$, lysine $\left(9 \mathrm{mg} 100 \mathrm{mg}^{-1}\right)$, alanine

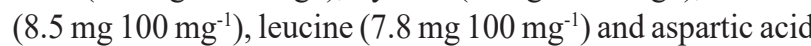
(7.5 mg $100 \mathrm{mg}^{-1}$ ) (Table.1). After hydrolysis, there were changes in the proportions of few amino acids. The amino acids lost upon hydrolysis included histidine, arginine, aspartic acid, glutamic acid and methionine. Some of the amino acids also increased upon hydrolysis viz., glycine, alanine, tyrosine, serine and taurine. There was no significant variation in the proportions of the remaining amino acids $(\mathrm{p}>0.05)$.

In the purified peptide fractions, loss of histidine was predominant except in the peptide fraction with MW 3-5 KDa. Hydroxy-lysine 1, increased from $0.91 \mathrm{mg}^{100 \mathrm{mg}^{-1}}$ to $0.49 \mathrm{mg} 100 \mathrm{mg}^{-1}$, but later reduced in peptide fraction with $\mathrm{MW}<3 \mathrm{KDa}$. Lysine remained almost constant. Arginine reduced in the peptides with lower MW, aspartic acid reduced in the peptides with MW 5-10 KDa, while glutamic acid reduced by $40-50 \%$ in the peptide fractions. Asparagine showed slight variation in the peptides.

Tyrosine increased from $1.2 \mathrm{mg} 100 \mathrm{mg}^{-1}$ to a maximum of $8.3 \mathrm{mg} 100 \mathrm{mg}^{-1}$ in the peptides with $\mathrm{MW}<5 \mathrm{KDa}$ and further decreased to $2.63 \mathrm{mg} 100 \mathrm{mg}^{-1}$ in $<3 \mathrm{KDa} \mathrm{MW}$ peptides. Phenylalanine and proline remained more or less similar in the peptides. Serine, on the other hand, increased from $0.92 \mathrm{mg} 100 \mathrm{mg}^{-1}$ to maximum of $1.62 \mathrm{mg} 100 \mathrm{mg}^{-1}$ in peptide fractions with $\mathrm{MW}<3 \mathrm{KDa}$. Cysteine did not show any change except in $<3 \mathrm{KDa}$ fraction with $0.04 \mathrm{mg} 100 \mathrm{mg}^{-1}$. Methionine reduced significantly with the reduction in the molecular size of peptides, particularly from $0.9 \mathrm{mg} 100 \mathrm{mg}^{-1}$ to $0.07 \mathrm{mg} 100 \mathrm{mg}^{-1}$ in $<3 \mathrm{KDa}$ peptide fraction. Threonine did not increase or decrease significantly in the peptides. Proline is the major cyclic acid present in appreciably higher concentration $\left(6.5 \mathrm{mg} 100 \mathrm{mg}^{-1}\right)$ in squid, SPH and in their peptide fractions.

Glycine increased from $14.85 \mathrm{mg} 100 \mathrm{mg}^{-1}$ to a maximum of $20.6 \mathrm{mg} 100 \mathrm{mg}^{-1}$ in peptides. Peptides below $\mathrm{MW}<5 \mathrm{KDa}$ contained more glycine. Alanine also increased in a similar way from $8.5 \mathrm{mg} 100 \mathrm{mg}^{-1}$ to $12.6 \mathrm{mg} 100 \mathrm{mg}^{-1}$. Valine and leucine showed slight increase in proportion, while isoleucine remained more or less constant in the peptides with the decrease in molecular size. Proportion of 


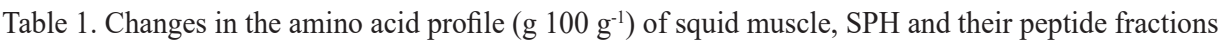

\begin{tabular}{|c|c|c|c|c|c|c|}
\hline Amino acid & Muscle & SPH & $<30 \mathrm{Kda}$ & $<10 \mathrm{Kda}$ & $<5 \mathrm{KDa}$ & $<3 \mathrm{KDa}$ \\
\hline His & $0.70 \pm 0.02$ & $0.13 \pm 0.01$ & $0.77 \pm 0.02$ & $0.06 \pm 0.01$ & $0.63 \pm 0.01$ & $0.00 \pm 0.01$ \\
\hline Lys & $8.91 \pm 0.11$ & $8.55 \pm 0.12$ & $8.24 \pm 0.11$ & $8.10 \pm 0.13$ & $8.16 \pm 0.12$ & $9.70 \pm 0.14$ \\
\hline HyLys1 & $0.19 \pm 0.01$ & $0.49 \pm 0.04$ & $0.42 \pm 0.07$ & $0.39 \pm 0.05$ & $0.39 \pm 0.04$ & $0.23 \pm 0.02$ \\
\hline Arg & $4.81 \pm 0.05$ & $3.31 \pm 0.04$ & $2.79 \pm 0.6$ & $2.72 \pm 0.02$ & $2.21 \pm 0.01$ & $1.37 \pm 0.02$ \\
\hline Basic & 14.62 & 12.49 & 12.22 & 11.27 & 11.39 & 11.31 \\
\hline Asp & $7.51 \pm 0.12$ & $3.63 \pm 0.11$ & $7.31 \pm 0.15$ & $5.56 \pm 0.13$ & $6.64 \pm 0.12$ & $7.05 \pm 0.16$ \\
\hline Glu & $11.97 \pm 0.13$ & $5.86 \pm 0.14$ & $5.92 \pm 0.17$ & $7.32 \pm 0.12$ & $6.32 \pm 0.16$ & $5.78 \pm 0.13$ \\
\hline Acidic & 19.48 & 9.49 & 13.23 & 12.88 & 12.96 & 12.83 \\
\hline Gln & $0.00 \pm 0.0$ & $0.00 \pm 0.0$ & $0.00 \pm 0.0$ & $0.00 \pm 0.0$ & $0.00 \pm 0.0$ & $0.00 \pm 0.0$ \\
\hline Asn & $1.17 \pm 0.01$ & $0.81 \pm 0.02$ & $0.89 \pm 0.01$ & $0.56 \pm 0.01$ & $1.07 \pm 0.02$ & $0.43 \pm 0.02$ \\
\hline Neutral & 1.17 & 0.81 & 0.89 & 0.56 & 1.07 & 0.43 \\
\hline Phe & $2.92 \pm 0.07$ & $2.01 \pm 0.01$ & $1.96 \pm 0.08$ & $2.05 \pm 0.07$ & $2.31 \pm 0.10$ & $2.59 \pm 0.12$ \\
\hline Tyr & $1.26 \pm 0.04$ & $3.81 \pm 0.06$ & $4.29 \pm 0.09$ & $3.07 \pm 0.10$ & $6.52 \pm 0.08$ & $2.63 \pm 0.12$ \\
\hline Aromatic & 4.17 & 5.82 & 6.25 & 5.12 & 8.83 & 5.22 \\
\hline Pro & $6.39 \pm 0.12$ & $6.51 \pm 0.11$ & $6.30 \pm 0.11$ & $6.13 \pm 0.12$ & $6.48 \pm 0.13$ & $6.50 \pm 0.12$ \\
\hline Ser & $0.92 \pm 0.03$ & $1.24 \pm 0.01$ & $1.08 \pm 0.01$ & $1.35 \pm 0.04$ & $1.11 \pm 0.02$ & $1.60 \pm 0.08$ \\
\hline Cys & $0.11 \pm 0.01$ & $0.00 \pm 0.0$ & $0.11 \pm 0.01$ & $0.17 \pm 0.01$ & $0.15 \pm 0.02$ & $0.04 \pm 0.01$ \\
\hline Thr & $2.13 \pm 0.09$ & $1.95 \pm 0.10$ & $1.79 \pm 0.12$ & $2.42 \pm 0.11$ & $2.53 \pm 0.14$ & $2.60 \pm 0.11$ \\
\hline Met & $0.90 \pm 0.06$ & $0.38 \pm 0.02$ & $0.33 \pm 0.03$ & $0.39 \pm 0.01$ & $0.08 \pm 0.01$ & $0.07 \pm 0.01$ \\
\hline Cyclic & 10.45 & 10.08 & 9.61 & 10.46 & 10.36 & 10.80 \\
\hline Gly & $14.85 \pm 0.16$ & $14.26 \pm 0.12$ & $14.77 \pm 0.12$ & $15.28 \pm 0.11$ & $17.98 \pm 0.09$ & $20.65 \pm 0.01$ \\
\hline Ala & $8.55 \pm 0.12$ & $8.73 \pm 0.11$ & $8.66 \pm 0.11$ & $9.96 \pm 0.15$ & $10.60 \pm 0.12$ & $12.60 \pm 0.02$ \\
\hline Val & $4.71 \pm 0.11$ & $4.70 \pm 0.13$ & $4.58 \pm 0.11$ & $5.19 \pm 0.12$ & $5.18 \pm 0.11$ & $5.51 \pm 0.11$ \\
\hline Ile & $4.61 \pm 0.12$ & $4.59 \pm 0.11$ & $4.49 \pm 0.13$ & $4.92 \pm 0.11$ & $4.68 \pm 0.11$ & $4.75 \pm 0.13$ \\
\hline Leu & $7.77 \pm 0.14$ & $7.83 \pm 0.12$ & $7.65 \pm 0.12$ & $8.40 \pm 0.16$ & $8.77 \pm 0.19$ & $9.58 \pm 0.12$ \\
\hline Aliphatic & 40.50 & 40.11 & 40.16 & 43.75 & 40.88 & 53.09 \\
\hline Tau & $1.97 \pm 0.09$ & $1.66 \pm 0.10$ & $1.57 \pm 0.11$ & $1.97 \pm 0.12$ & $2.31 \pm 0.09$ & $3.51 \pm 0.08$ \\
\hline Sulphonic & 1.97 & 1.66 & 1.57 & 1.97 & 2.31 & 3.51 \\
\hline Total & 92.36 & 80.46 & 83.93 & 86.01 & 87.80 & 97.19 \\
\hline
\end{tabular}

taurine in squid was quite high $\left(1.9 \mathrm{mg} 100 \mathrm{mg}^{-1}\right)$ and later it increased to $3.5 \mathrm{mg} 100 \mathrm{mg}^{-1}$ in peptides with $\mathrm{MW}<3 \mathrm{KDa}$.

\section{DPPH radical scavenging activity}

DPPH radical scavenging activities of the SPH and their peptide fractions are given in Fig. 2. SPH exhibited $89 \%$ DPPH inhibition after $30 \mathrm{~min}$ of hydrolysis. Peptide fractions with MW $>30 \mathrm{KDa}$ had 51\% DPPH inhibition, while those with MW $<30 \mathrm{KDa}$ had $63 \%$ DPPH inhibition. DPPH inhibition further increased with the decrease in molecular size of the peptides and those fractions with $\mathrm{MW}<3 \mathrm{KDa}$ showed the maximum DPPH inhibition of $95 \%$ at $10 \mathrm{mg} \mathrm{ml}^{-1}$ of protein concentration. Results showed that peptide fraction with MW $<3 \mathrm{KDa}$ had better DPPH inhibition than SPH, proving that purification to lower molecular size provide peptides with more antioxidative activities. DPPH inhibition expressed by squid peptides were much higher than $100 \mathrm{ppm}$ of BHA (70\%). Similar to our findings, mackerel muscle hydrolysates with MW of $1.4 \mathrm{KDa}$ also possessed a stronger antioxidant activity (Wu et al., 2003).

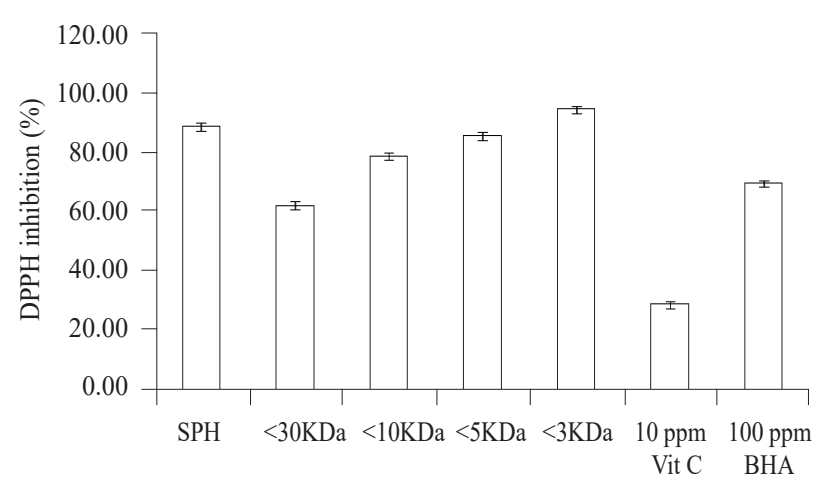

Fig. 2. DPPH radical scavenging activities of TPH and their peptide fractions prepared using alcalase in comparison with commercial antioxidants

Antioxidant activity of FPH has been reported to be mainly dependent on the enzymes, hydrolysis conditions, size of the peptides and their sequences (Clare, 2000; Arihara, 2004). Initially, alkaline (basic) amino acids were reported to provide strong DPPH antioxidant activity in royal jelly and grass carp muscle hydrolysates (Ren et al., 2008; 
Guo et al., 2009). But, in SPH and their peptides, alkaline (basic) amino acids decreased with decrease in the molecular size of the peptides and are therefore not responsible for this activity. Later, studies on the peptide profile of hemp protein hydrolysates indicated that hydrophobic amino acids exhibited DPPH inhibition (Xiansheng et al., 2009). In support to this, the proportion of these amino acids in SPH increased from 40 to $53 \%$ in the squid peptides and more specifically glycine, alanine, leucine and valine. Xiaoqing et al. (2013) identified that among the hydrophobic amino acids, leucine, phenylalanine and valine had contributed towards high DPPH inhibition in clam (Paphia undulata) hydrolysates. In this study, phenylalanine did not increase, to contribute for the high DPPH inhibition. But an increase in tyrosine, serine and taurine was observed with increase in molecular size of squid peptides, which could also contribute towards the antioxidant properties in addition to the hydrophobic amino acids.

\section{ABTS radical scavenging activity}

ABTS radical scavenging activities of SPH and their peptide fractions are given in Fig. 3. Unlike DPPH inhibition, significant differences in the ABTS radical scavenging activities were observed between SPH and their peptide fractions with $\mathrm{MW}<5 \mathrm{KDa}$ and those with $\mathrm{MW}$ between $10-30 \mathrm{KDa}(\mathrm{p}>0.05)$. ABTS inhibition was generally higher in SPH (94\%) and it got reduced in peptide fractions with higher MW 10-30 KDa to $42 \%$. However, the activity further increased in peptides with $\mathrm{MW}<5 \mathrm{KDa}$ and was found to be maximum in 3KDa peptides with $97 \%$. The ABTS inhibition expressed by squid peptides with $<3 \mathrm{KDa}$ was much higher than the activity of $10 \mathrm{ppm}$ BHA (70\%) and almost equal to 100 ppm vitamin C (100\%).

The presence of hydrophilic amino acids has been reported to be responsible for higher ABTS activity in the ornate threadfin bream muscle hydrolysates prepared with pepsin extracted from skipjack tuna (Nalinanona

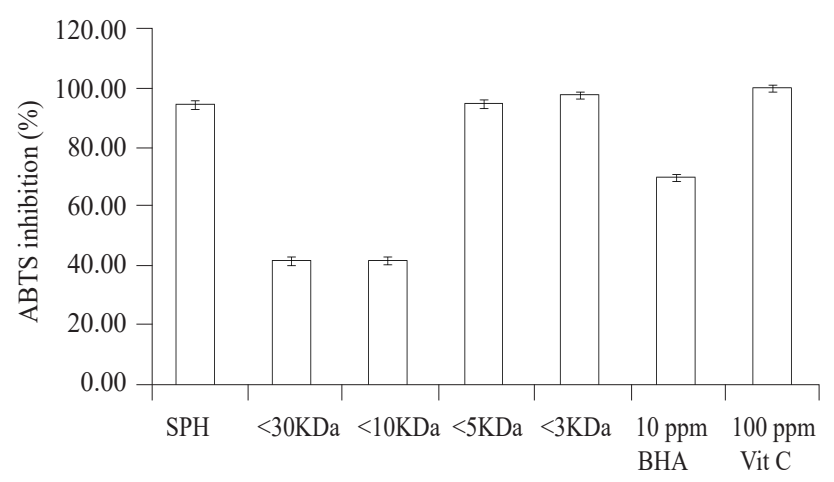

Fig. 3. ABTS radical scavenging activities of TPH and their peptide fractions prepared using alcalase in comparison with commercial antioxidants et al., 2011). In this study, the hydrophilic amino acids viz., aspartic acid, tyrosine and asparagine have been identified as the major amino acids responsible for ABTS inhibition, as the proportion of these amino acids was similar in SPH and the peptide fractions with $\mathrm{MW}<5 \mathrm{KDa}$. Hydrophobic amino acids and taurine could also contributed to ABTS radical inhibition.

\section{Hydroxyl radical scavenging activity}

Hydroxyl radicals are generally formed from superoxide anion and hydrogen peroxide in the presence of transition metal ions such as $\mathrm{Fe}^{2+}$ and $\mathrm{Cu}^{2+}$. SPH exhibited $75 \%$ hydroxyl radical inhibition with $96 \%$ at $10 \mathrm{mg} \mathrm{ml}^{-1}$ concentration (Fig. 4). Hydroxyl radical scavenging activities of shrimp muscle hydrolysates at $5 \mathrm{mg} \mathrm{ml}^{-1}$ concentration have been reported (Cao et al., 2009). Peptide fractions with higher MW generally have lower hydroxyl radical inhibition than those with lower MW. Hydroxyl radical inhibition increased from $74 \%$ to a maximum of $97 \%$ with the decrease in MW from $>30 \mathrm{KDa}$ to $<3 \mathrm{KDa}$. In an earlier report, purified peptides derived from Alaska pollack (Theragra chalcogramma) exhibited only $35 \%$ inhibition (Je et al., 2005), but the

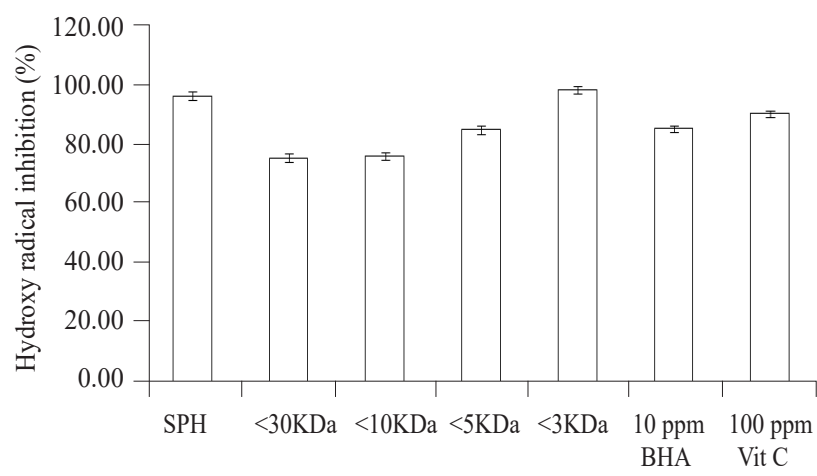

Fig. 4. Hydroxyl radical scavenging activities of TPH and their peptide fractions prepared using alcalase in comparison with commercial antioxidants

purified squid peptides showed more inhibition than the SPH itself. Similar to our findings, peptide fraction with $3 \mathrm{KDa}$ of grass carp muscle hydrolysate prepared using alcalase exhibited higher hydroxyl radical scavenging activity (Ren et al., 2008). Hydroxyl radical scavenging activities were also reported to be much higher in puffer fish skin gelatin hydrolysates and low MW peptides with $<5 \mathrm{KD}$ a than vitamin $\mathrm{C}$ and $\mathrm{E}$ (Zhu et al., 2008). In this study, the hydroxyl activity expressed by squid peptides was higher than $10 \mathrm{ppm}$ of BHA $(85 \%)$ and $10 \mathrm{ppm}$ of vitamin (90\%).

Suetsuna et al. (2000) suggested that the phenolic groups in phenylalanine and tyrosine contribute more for the hydroxyl radical scavenging activity through electron donation. According to $\mathrm{Li}$ et al. (2003), the presence of 
high phenylalanine in the peptides showed high hydroxyl radical scavenging activity due to the reaction of aromatic ring with hydroxyl radical to form a stable compound. More specifically, tyrosine at C-terminal was also found to be responsible for hydroxyl radical inhibition based on the three peptides sequenced from royal jelly protein hydrolysates (Guo, 2009). In this study, phenylalanine did not show any increase in the peptides of smaller MW, instead tyrosine increased in the squid peptides with the decrease in MW (except $<3 \mathrm{KDa}$ ) and hence, the findings partially support the earlier report. In addition, the hydrophobic amino acids, serine and taurine that had increased in peptides contribute for the hydroxyl inhibition by the squid peptide fractions.

Very high DPPH (95\%), ABTS (98\%) and hydroxyl radicals $(98 \%)$ scavenging activities of squid peptides with MW $<3 \mathrm{KDa}$ could be related to some unusual changes in the amino acid profile. For instance, the proportion of hydrophobic amino acid was $53 \%$ in the squid peptides as against $40 \%$ in SPH. Increase in hydrophobic amino acids is mainly because of the catalytic sites of alcalase, which are peptide bonds of aliphatic or aromatic amino acids viz., leucine, phenyl alanine, tyrosine and tryptophan (Rao et al., 1998). Loss of histidine as well as asparagine was very prominent. Gain of serine, glycine, alanine and taurine was found quite unique. Taurine has been identified to be involved in radical scavenging activities, membrane regulation, osmoregulation and regulation of calcium homeostasis (Larsen et al., 2007). Also, taurine has been reported to lower cholesterol absorption due to enhancement of cholesterol degradation and excretion of the bile acid (Yokogoshi et al., 1999). Increase in taurine in squid peptides thus provides additional benefits apart from antioxidative properties. In squid peptides of lower molecular size, histidine did not contribute to any antioxidative activity, however, increase in the proportions of hydrophobic amino acids in addition to serine and taurine was found responsible for the radical scavenging activities in squid peptides.

Purified peptides with MW $<5 \mathrm{KDa}$ possessed more DPPH, ABTS and hydroxyl radical scavenging activities than $\mathrm{SPH}$ and their peptides with $\mathrm{MW}>5 \mathrm{KDa}$. Amino acid profile showed differences among raw squid, SPH and their peptides fractions. Predominance of lysine, aspartate, glutamate, proline, glycine, alanine, leucine, valine, isoleucine and taurine was noticed in the squid peptides of lower molecular weights. Hydrophobic amino acids taurine and serine were responsible mainly for the antioxidative properties. Cyclic amino acid, proline is a unique one in squid contributing for special antioxidative property unlike fish peptides. This study thus helped to understand the changes in the different amino acid profiles of the different molecular size peptides of squid and their resultant antioxidant activities. In addition, it also indicated that the increase in taurine, provides cholesterol lowering effect in addition to antioxidative properties in squid peptides. These low molecular weight squid peptides can be prepared commercially using tangential flow filter (TFF) systems, cost effectively for incorporation in functional food products.

\section{Acknowledgements}

The authors thank the Dean, Fisheries College and Research Institute, Tamil Nadu Fisheries University, Thoothukudi for providing necessary facilities to undertake this work. The authors gratefully acknowledge the financial support given by the Department of Science and Technology (DST), Government of India (GOI), New Delhi to carry out this research work.

\section{References}

Adler-Nissen, J. 1986. Enzymic hydrolysis of food proteins. Elsevier Applied Science Publishers, Barking, UK

Aleman, A., Gimenez, B., Montero, P. and Gomez-Guillen, M. C. 2011. Antioxidant activity of several marine skin gelatins LWT. Food Sci. Technol., 44: 407-413.

AOAC 1995. Official methods of analysis, $16^{\text {th }}$ edn. Association of Official Analytical Chemists, Arlington, USA

Arihara, K. 2004. Functional foods. In: Jensen, W. K., Devine, C. and Dikeman, M. (Eds.), Encyclopedia of meat sciences. Elsevier, Oxford, UK, p. 492-499.

Aspmo, S. I., Horn, S. J. and Eijsink, V. G. H. 2005. Enzymatic hydrolysis of Atlantic cod (Gadus morhua L.) viscera. Process Biochem., 40: 1957-1966.

Beak, H. H. and Cadwallader, K. R. 1995. Enzymatic hydrolysis of crayfish processing byproducts. J. Food Sci., 60: 929-935.

Byun, H. G. and Kim, S. K. 2001. Purification and characterisation of angiotensin I converting enzyme (ACE) inhibitory peptides from Alaska pollack (Theragra chalcogramma) skin. Process Biochem., 36: 1155-1162.

Cao, W., Zhang, C., Hong, P. and Ji, H. 2009. Optimising the free radical scavenging activity of shrimp protein hydrolysate produced with alcalase using response surface methodology, Int. J. Food Sci. Technol., 44: 1602-1608.

Christensen, R. 1996. Analysis of variance, design and regression: Applied statistical methods. Chapman \& Hall, New York, USA.

Clare, D. A. and Swaisgood, H. E. 2000. Bioactive milk peptides: a prospectus. J. Dairy Sci., 83: 1187-1195.

Crowell, E. A., Ough, C. S. and Bakalinsky, A. 1985. Determination of alpha amino nitrogen in musts and wines by TNBS Method. Am. J. Enol. Vitic., 36: 175-177.

Gimenez, B., Aleman, A., Montero, P. and Gomez-Guillen, M. C. 2009. Antioxidant and functional properties of gelatin hydrolysates obtained from skin of sole and squid. Food Chem., 114(3): 976- 983.

Gomez-Guillen, M. C., Lopez Caballero, M. E., Aleman, A., Lopez de Lacey, A., Gimenez, B. and Montero, P. 2010. Sea 
byproducts as real material: new ways of application, Transworld Research Network 37/661 (2), Trivandrum, Kerala, India, p. 89-115.

Guo, H., Kouzuma, Y. and Yonekura, M. 2009. Structures and properties of antioxidative peptides derived from royal jelly protein. Food Chem., 113: 238-245.

Hoyle, N. T. and Merritt, J. H. 1994. Quality of fish protein hydrolysate from herring (Clupea harengus). J. Food Sci., 59: 76-79.

Hsu, K. C., Lu, G. H. and Jao, C. L. 2009. Antioxidative properties of peptides prepared from tuna cooking juice hydrolysates with orientase (Bacillus subtilis). Food Res. Int., 42(5-6): 647-652.

Ishida, Y., Fujita, T. and Arai, K. 1981. New detection and separation method for amino acid by high performance liquid chromatography. J. Chromatogr., 204: 143-148.

Je, J. Y., Park, P. J. and Kim, S. K. 2005. Antioxidant activity of a peptide isolated from Alaska pollack (Theragra chalcogramma) frame protein hydrolysate. Food Res. Int., 38: $45-50$

Je, J. Y., Qian, Z. J., Byun, H. G. and Kim, S. K. 2007. Purification and characterisation of an antioxidant peptide obtained from tuna backbone protein by enzymatic hydrolysis. Process Biochem., 42: 840-846.

Kim, S. K. and Wijesekara, I. 2010. Development and biological activities of marine-derived bioactive peptides: a review. J. Functional Foods, 2: 1-9.

Klompong, V., Benjakul, S., Kantachote, D. and Shahidi, F. 2007. Antioxidative activity and functional properties of protein hydrolysate of yellow stripe trevally (Selaroide sleptolepis) as influenced by the degree of hydrolysis and enzyme type. Food Chem., 102(4): 1317-1327.

Kristinsson, H. G. and Rasco, B. A. 2000. Biochemical and functional properties of Atlantic salmon (Salmo salar) muscle proteins hydrolysed with various alkaline proteases. J. Agri. Food Chem., 48: 657-666.

Larsen, R. S. K., Stormo, B. T., Dragnes, E. O. and Elvevo I. I. 2007. Losses of taurine, creatine, glycine and alanine from cod (Gadus morhua L.) fillet during processing. J. Food Comp. Anal., 20: 396-402.

Li, M., Carlson, S., Kinzer, J. A. and Perpall, H. J. 2003. HPLC and LC-MS studies of hydroxylation of phenylalanine as an assay for hydroxyl radicals generated from Udenfriend's reagent. Biochem. Biophy. Res. Com., 312(2): 316-322.

Lowery, S., Slayter, H. S., Weeds, A. G. and Baker, H. 1969. Substructure of the myosin molecule I. Sub fragment of myosin by enzymatic degradation. J. Mol. Biol., 42: 1.

Mendis, E., Rajapakse, N., Byun, H. and Kim, S. 2005. Investigation of jumbo squid (Dosidicus gigas) skin gelatin peptides for their in-vitro antioxidant effects. Life Sci., 77(17): 2166-2178.

Nalinanona, S., Benjakul, S., Kishimura, H. and Shahidi, F. 2011. Functionalities and antioxidant properties of protein hydrolysates from the muscle of ornate threadfin bream treated with pepsin from skipjack tuna. Food Chem., 124: 1354-1362.

Pihlanto-Leppala, A., Rokka, T. and Angiotensin-Korhonen, H. I. 2001. Converting enzyme inhibitory peptides derived from bovine milk proteins. Int. Dental J., 8: 325-331.

Rajapakse, N., Mendis, E., Byun, H. and Kim, S. 2005. Purification and in vitro antioxidative effects of giant squid muscle peptides on free radical-mediated oxidative systems. J. Nutr. Biochem., 16(9): 562-569.

Rao, M. B., Tanksale A. M., Ghatge, M. S. and Deshpande, V. V. 1998. Molecular and biotechnological aspects of microbial proteases. Microbiol. Mol. Bio. Rev., 62(3): 597-635.

Ren, J., Zhao, M., Shi, J., Wang, J., Jiang, Y., Cui, C., Kakuda, Y. and Xue, S. J. 2008. Purification and identification of antioxidant peptides from grass carp muscle hydrolysates by consecutive chromatography and electrospray ionisationmass spectrometry. Food Chem., 108(2): 727-736.

Sarmadi, B. H. and Ismail, A. 2010. Antioxidative peptides from food proteins: A review. Peptides, 31: 1949-1956.

Shalaby, E. A. and Shanab, S. M. M. 2013. Comparison of DPPH and ABTS assays for determining antioxidant potential of water and methanol extracts of Spirulina platensis. Indian J. Geo-Mar., Sci., 42(5): 556-564

Simpson, B. K., Nayeri, G., Yaylayan, V. and Ashie, N. A. 1998. Enzymatic hydrolysis of shrimp meat. Food Chem., 61(1/2): 131-138.

Smirnoff, N. and Cumbes, Q. J. 1989. Hydroxyl radical scavenging activity of compatible solutes. Phytochemistry, 28: $1057-1060$

Suetsuna, K., Ukeda, H. and Ochi, H. 2000. Isolation and characterisation of free radical scavenging activities peptides derived from casein. J. Nutr. Biochem., 11(3): 128-131.

Thiansilakul, Y., Benjakul, S. and Shahidi, F. 2007. Compositions, functional properties and antioxidative activity of protein hydrolysates prepared from round scad (Decapterus maruadsi). Food Chem., 103: 1385-1394.

Viera, G. H. F., Martin, A. M., Sampaiao, S. S., Omar, S. and Gonsalves, R. C. F. 1995. Studies on the enzymatic hydrolysis of Brazilian lobster (Panulirus spp.) processing wastes. J. Food Sci. Agric., 69: 61-65.

Wu, H. C., Chenb, H. M. and Shiaua, C. Y. 2003. Amino acids and peptides as related to antioxidant properties in protein hydrolysates of mackerel (Scomber austriasicus). Food Res. Int., 36: 949-957.

Xian-Sheng, W., Chuan-He, T., Ling, C. and Xiao-Quan, Y 2009. Characterisation and antioxidant properties of hemp protein hydrolysates obtained with neutrase. Food Technol. Biotechnol., 47(4): 428-434.

Xiaoqing, H. E., Wenhong, C. A. O., Zike, Z. and Chaohua, Z. 2013. Analysis of protein composition and antioxidant activity of hydrolysates from Paphia undulata. J. Food Nutr. Res., 1(3): 30-36. 
Yang, J., Ho, H., Chu, Y. and Chow, C. 2008a. Characteristic and antioxidant activity of retorted gelatin hydrolysates from cobia (Rachycentron canadum) skin. Food Chem., 110(1): 128-136.

Yang, H., Wang, Y., Zhou, P. and Regenstein, J. M. 2008b. Effects of alkaline and acid pretreatment on the physical properties and nanostructures of the gelatin from channel catfish skins. Food Hydrocolloids, 22: 1541-1550.
Yokogoshi, H., Mochizuki, H., Nanami, K., Hida, Y., Miyachi, F. and Hiroaki, O. H. 1999. Dietary taurine enhances cholesterol degradation and reduces serum and liver cholesterol concentrations in rat fed high-cholesterol diet. J. Nutr., 129: 1705-1712.

Zhu, B., Zhou, D., Li, D. and Ren, J. 2008. Free radical scavenging activity of gelatin hydrolysate from puffer fish skin, Takifugu rubripes. J. Biotechnol., 136: 589-601. 